\section{Allianser og overføringer ved psykoterapi}

Bruk av overføringstolkninger i psykoterapi må tilpasses kvaliteten på den terapeutiske alliansen.

I litteraturen om virksomme faktorer i psykoterapi har uspesifikke faktorer, blant annet den terapeutisk allianse, versus spesifikke teknikker, for eksempel overføringstolkninger, vært en kilde til uenighet siden 1930-årene. Disse faktorene er gjerne blitt satt opp mot hverandre og slik har man fostret ideen om at det enten er teknikk eller allianse som er årsaken til endringene som skjer i psykoterapeutisk behandling. I bare noen få naturalistiske studier har man sett på virkningen av allianse og teknikk sammen.

De fleste sentrale teoretikere i den psykoanalytiske tradisjon hevder at både gode objektrelasjoner, dvs. kvalitet i viktige mellommenneskelige relasjoner, og en god terapeutisk allianse er forutsetninger for at overføringstolkninger skal virke positivt. Nå er dette undersøkt av forskere i den norske FEST-studien (1).

Resultatene viste at objektrelasjoner, allianse og overføringstolkninger inngår $i$ et systematisk samspill - en treveis interaksjon. God terapeutisk allianse var forbundet med gode resultater i begge behandlingsgruppene, som i mange tidligere studier. Men forholdet mellom terapeutisk allianse og de spesifikke effektene av overføringsarbeid, dvs. forskjellen på terapi med og uten overføringstolkninger, forandret seg avhengig av nivået av kvaliteten i pasientenes relasjoner. For pasienter med langvarige konfliktfylte relasjoner, ensomhet og mer alvorlige psykopatologiske avvik var effekten av overføringsarbeid positiv, enten alliansen var god eller dårlig. For friskere og mer ressurssterke pasienter var den spesifikke effekten av overføringstolkninger også positiv dersom alliansen var lav, men negativ, dvs. at terapi uten overføringstolkninger var mer effektivt, dersom alliansen var høy. Dette er stikk i strid med det som vanligvis hevdes i lærebøker.

Pasienter med gode relasjoner og god allianse med legen har best nytte av behandling uten overføringsarbeid. Men legen bør spørre pasientene direkte om hvordan hun/han opplever behandlingen. Dersom det er tegn til at det er problemer

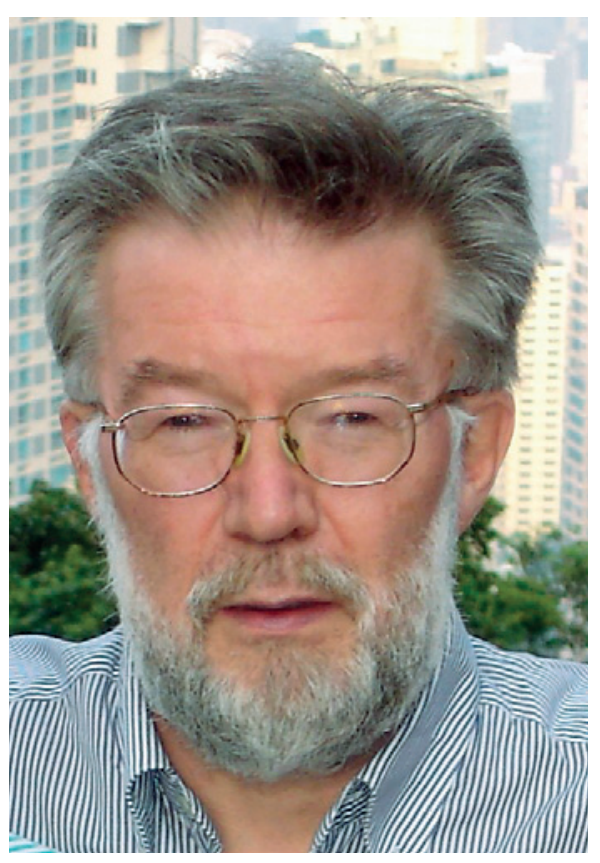

Per A. Høglend, studiens førsteforfatter. Foto Stein H. Olsen

i samarbeidet, bør dette belyses ved overføringsarbeid. Problemene kan skyldes pasientens personlighetsmessige vansker, f.eks. objektrelasjoner av dårlig kvalitet , men det kan også skyldes uenigheter eller misforståelser om hvordan behandlingen bør være og/eller manglende tiltro til terapeuten (dvs. lav allianse). Leger gjør klokt $\mathrm{i}$ å være åpne om at de selv kan ha bidratt til problemene. A ta opp dette direkte med pasienten, på en måte som gjør at pasienten ikke føler seg kritisert eller bebreidet, kan bedre resultatene, ikke bare i psykoterapi, men sannsynligvis også $\mathrm{i}$ andre typer behandlinger.

\section{Erlend Hem}

erlend.hem@medisin.uio.no

Tidsskriftet

\section{Litteratur}

1. Høglend P, Hersoug AG, Bøgwald KP et al. Effects of transference work in the context of therapeutic alliance and quality of object relations. J Consult Clin Psychol 2011; 79: 697-706.
Ordforklaringer

FEST-studien (First Experimental Study of Transference-interpretation) er en randomisert klinisk studie med dismantling design, spesielt utformet for å måle langtidseffektene av overføringstolkninger, og hvem som har nytte av slike tolkninger. 100 pasienter ble randomisert til ett års dynamisk psykoterapi med og uten overføringstolkninger, og ble fulgt opp i tre år etter avsluttet terapi. Forskerne har tidligere rapportert at den halvparten av pasientene som hadde et langvarig mønster av problematiske mellommenneskelige relasjoner, mer alvorlige psykopatologiske manifestasjoner og personlighetsforstyrrelser, overraskende hadde mest nytte av overføringsarbeid (1). Effektene holdt seg i hele treårsperioden etter terapiavslutning (2), og økning i selvinnsikt under terapien forklarte (medierte) mesteparten av langtidseffektene (3).

Objektrelasjoner er pasientens evne til å danne gjensidige, givende og stabile relasjoner til flere viktige personer i livet. Dårlige objektrelasjoner er preget av manglende gjensidighet, avhengighet, utnytting, manglende stabilitet og mindre emosjonell investering.

Overføring er et uttrykk lansert av Sigmund Freud (1856-1939). Analyse av overføringen er den sentrale teknikken i psykodynamisk psykoterapi. Terapeut-pasient-forholdet er farget av pasientens tidligere eller nåværende relasjoner og følelsesmessige erfaringer. Nettopp derfor kan overføringstolkninger gi en sterk emosjonell opplevelse og belyse viktige sider av pasientens problemer i mellommenneskelige relasjoner.

\section{Litteratur}

1. Hem E. Når er overføringstolkninger nyttige? Tidsskr Nor Lægeforen 2007; 127: 407.

2. Hem E. Effekten av overføringstolkninger varer lenge. Tidsskr Nor Legeforen 2008; 128: 1263.

3. Hem E. Innsikt gir langtidseffekt ved psykoterapi. Tidsskr Nor Legeforen 2010; 130: 1695

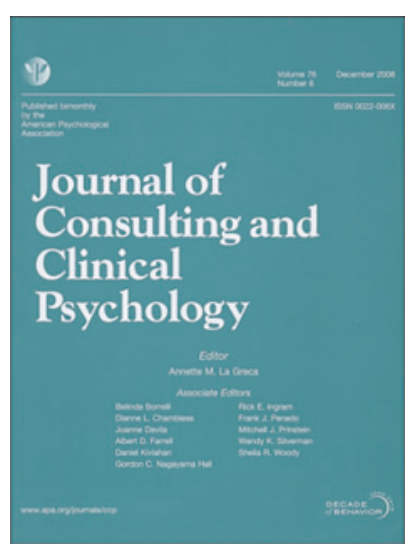

Artikkelen ble publisert i oktobernummeret 2011 av Journal of Consulting and Clinical Psychology (www.apa.org/pubs/journals/ ccp), som er et av de høyest rangerte tidsskriftene i klinisk psykologi. 